\title{
Ethics scrutiny needed for Chinese-European projects
}

Biomedical research collaborations between Europe and China need greater ethical oversight to combat unregulated stem-cell therapies and prevent the exploitation of clinical-trial participants. That's the message from a group of bioethics experts who are part of the Chinese-European BIONET project, a partnership set up to examine scientific collaborations between the regions. Over the past three years, it has run a series of workshops in China to produce a set of best-practice guidelines for scientists working in fields such as reproductive and regenerative medicine, stem-cell research and human-tissue biobanking.

The group's draft recommendations, presented at the final BIONET meeting in London on 2-4 September, include a call for a joint advisory body made up of experts from participating countries, to offer advice and monitor research practices. The body could be financed by funding agencies, research institutions and state authorities, BIONET suggests.

"We have no police force," says BIONET member Ole Döring, an ethicist at the German Institute of Global and Area Studies in Hamburg. "We are proposing that if you install a body that would supervise and provide guidance, just the fact it exists will help create transparency."

The BIONET expert group warns that legal, political, social and cultural differences between European nations and China can lead to "multiple standards and even to gaps in between governance regimes". BIONET coordinator Nikolas Rose, a sociologist at the BIOS centre at the London School of Economics, says that there is a pressing need to address such issues because "the number of Chinese scientists who are collaborating with European scientists is growing at a massive rate". A 2006 study by the consultancy Evidence, based in Leeds, UK, shows that the number of publications co-authored by researchers in China and the European Union rose from 1,320 to 4,568 between 1996 and 2005.

But Rose insists that the BIONET recommendations are not an attempt to force China to adopt Western research standards. "China is not the 'Wild East', it is not an ethics-free zone," he says.

The recommendations come less than a month after the China-UK Research Ethics (CURE) committee of the UK Medical Research Council (MRC) produced its own report on the subject, concluding that there is "comparatively little" inspection or review of compliance with research regulations in China. Qi Guoming, vice-chairman of the Chinese Medical Association and chairman of the medical ethics committee at the Chinese Ministry of Health, told the conference that the ministry was trying to come up with "more concrete regulations" for medical research, and that BIONET's recommendations could guide that process.

In May, for example, China toughened up its regulation of stemcell therapies (see Nature 459, 146-147; 2009). But there are still more than 100 institutions in China that continue to charge patients thousands of dollars for unproven stem-cell treatments, says Qiu Renzong, a bioethicist at the Chinese Academy of Social Sciences and co-chairman of the BIONET expert group.

BIONET's list of 30 recommendations includes establishing protocols to ensure that clinical trials of unproven therapies, such as stem-cell treatments, are not presented to patients as a cure. Research subjects should not be coerced into taking part in clinical trials, and all trial data should be published. BIONET also proposes that international ethical standards should be reflected by national regulation where possible, and that biobanks should ensure that any donors are fully informed about how their tissue will be used. The group adds that patients involved in clinical trials must have access to any beneficial therapies after the trials finish.

"Many of these recommendations reflect standards we would set for funding international collaboration," says Catherine Elliott, the MRC's head of clinical research support and ethics who coordinated the CURE report. "Some, however, would require much wider action and implementation than a single funder can provide." The new recommendations, she says, will trigger that wider discussion.

Daniel Cressey 